Suci Madalena ${ }^{1}$, Moses Glorino Rumambo Pandin ${ }^{2}$

Universitas Airlangga

Airlangga Street No.4-6, Airlangga, Gubeng District, Surabaya

suci.madalena-2020@fib.unair.ac.id, moses.glorino@fib.unair.ac.id

\title{
Book Review: "Buku Saku Millenial Mengawasi Pilkada 2020”
}

\author{
Khudrotun Nafisah; 2020; 978-623-92593-5-8; 54 Pages
}

The Pocketbook of Millennials Supervising the 2020 Pilkada was written to provide knowledge and guidance to the millennial generation in implementing the 2020 elections. The importance of implementing the 2020 Pilkada, of course, cannot be separated from the Pilkada organizers themselves. Some of the reasons why the election is important, namely as a means of directly choosing candidates to lead in the future, being able to know the programs and vision and mission of prospective leaders during their future tenure, and the election results will determine the future of the region being led. As a millennial citizen aged 17 and has the right to vote, we must be an intelligent voter by paying attention to several things, such as ensuring that he has been registered in the DPT. Observing every vision and mission conveyed by each candidate, recognizing the background and curriculum vitae of the candidate, ensuring choice with the consideration which is good and faithful, chooses with the applicable election rules which can be considered "legally," Participates in overseeing the voting and counting and does not hesitate to report if suspicious things and are included in election violations.

This book was written and published with the main target, the millennial generation, who already have rights and obligations in general elections. The role of the millennial generation as the organizer of the 2020 local elections is very much needed as the initial spearhead of participation and direct contribution to the people's democratic party. One of them is participating as a participatory supervisor. Supervising elections and the millennial generation can also contribute by choosing candidate leaders with the correct voting requirements.

The information obtained when reading this book is the correct and appropriate guide and reference from the General Election Commission Regulations for millennials who learn to follow election supervision. It is hoped that the millennial generation can be open to the democratic process in their nation by applicable regulations. Some things that millennials can monitor during elections are monitoring technical fraud, campaign behavior that is considered detrimental to specific groups, money politics, and abuse of state positions or facilities. That way, the millennial generation can participate in participatory supervision of the 2020 Regional Head General Election. This election usually includes the House of Representatives, Regional Representatives Council, regional heads, the president, and vice president. Also related to the Election of Regional Heads or commonly abbreviated as Pilkada, is an election that is focused on electing the Governor and Deputy Governor, Mayor and Deputy Mayor for those in the city area, as well as the election of the Regent and Deputy Regent for those who are in the regency area. The implementation of this election must be direct and democratic.

This book is excellent and relevant to be reviewed and a guide for the millennial generation overseeing the elections. Why is that? Because in the implementation of this, Pilkada will certainly produce leaders or regional heads in each region. Each regional head and deputy has duties, authorities, obligations, and prohibitions when carrying out the mandate as regional leaders. Some of the obligations are reporting the administration of local government to the superior government, reporting accountability to the DPRD, and finally reporting on the implementation to the community. Thus, how important it is that millennials must also participate in elections, namely to participate in realizing the provision of development facilities and infrastructures in each respective region, such as handling traffic jams and structuring roads, quality and populist health services, and disaster management, as well as electricity and clean water services for all levels of society. In the 2020 elections yesterday, several unique things need to be known, such as the shorter campaign period. If in previous elections the campaign period had 81 days, in 2020, it only got 71 days. This policy is considered the most efficient and appropriate considering the restrictions on meetings, face-to-face meetings, and other activities related to the campaign. In addition, the term of office of regional heads elected in 2020 only 
held positions for a maximum of 4 years, and some of them only served for 3.5 years. The term of office of regional heads is so short that there will be a change in regional election policy that will simultaneously be carried out in 2024 at the same time as the presidential election and the election of the state legislature.

The Pocket Book of Millennials Supervising the 2020 Pilkada has met readers' needs in understanding and understanding the guidelines for the millennial generation when participating in the elections. The majority of the contents of the book describe how to elect candidates coherently and correctly. The points regarding the electoral regulations are presented in a concise and easy for the reader to understand. In the current development of globalization, the need to disseminate information is so easy through online and offline media so that the target for the millennial generation can take place quickly and precisely.

The new information that we will get when reading the book Pocket Millennial Supervising the 2020 Pilkada is related to implementing the election and how we monitor millennial participants. Even regarding the meaning of the election and the 2020 elections. If we usually only understand briefly about LUBERJURDIL, this book explains in detail about the election organizers. The shorter 2020 campaign period is due to a situation that does not allow for too long holding in a pandemic situation and pressures Existing expenses.

The influence of the PocketBook Millennial Watching the Pilkada 2020 is enormous for the millennial generation who reads it. In the book, some points explain why the 2020 elections are important. Of course, the pilkada is essential to choose national leaders directly and independently, which will influence the region being led for the next five years. Furthermore, by knowing the importance of pilkada, we know the candidate program and election results so that this pocketbook will significantly influence the millennial generation to take part.

This pocketbook influences readers, namely the millennial generation, with the concept of carrying a sentence that is easy to understand and directly refers to essential points. Knowing how to become an intelligent voter listed on page 32 shows that it can motivate and serve as a guideline for the millennial generation so that they are not mistaken in choosing the nation's leader. Several matters related to the pilkada that must be monitored are also explained in chapter 5 to influence readers to monitor the pilkada from fraud, adverse campaign behavior, oversee money politics, and control against abuse of power.

In its presentation, this book does not forget to include evidence that strengthens the book's contents. Several chapters that discuss the role of millennials also include evidence that many of the millennial generations are carrying out duties in the seat of the state. If we look at the 2019 election, many new faces have been found in politics. Such as 52 members of the DPR RI, 1 Minister, and seven exceptional presidential staff from the millennial group. This evidence can convince the millennial generation that their participation in participating in this people's party is essential.

This book certainly also convinces the millennial generation that they have the right and obligation to participate in the implementation of regional elections. Departing from chapter 3, which explains whom the election participation is included in the millennial generation with the criteria of at least 17 years of age or married, no mental disorder, no revocation of voting rights, and several other conditions that require the people to elect a candidate for the nation's leader. All of these provisions are stated in the General Election Commission Regulations.

On page 41, it is stated that there are several millennial ways to oversee the 2020 elections. These methods are: Based on the supervision of the 2020 elections, the public, in general, can carry out supervision in the form of overseeing technical fraud in the implementation of elections, monitoring campaign behavior that is detrimental or harassing certain groups, supervising if the discovery of money politics games, as well as overseeing the abuse of office from the existence of state facilities.

Regarding the style, organization, and size of the book are by the author's goals. The language style uses standard language but is very easy to understand by using denotative language. As the title suggests, "pocketbook," this book is small in size and easy to carry everywhere. It can be seen as the advantage of a book that makes it easier for readers to store the book in a pocket or small bag without worrying about taking up much space. 
Regarding studies, facts, or ideas, the author ignores nothing. The entire content has been conveyed both by considering the provisions and articles contained in the election regulations and laws. The facts and ideas conveyed are also transparent with clear guidelines so that they are not easily swayed, or the quality of the writing is doubted.

The advantages of the Millennial Pocket Book Overseeing the 2020 Regional Head Elections are, of course, straightforward to find. This book explains the references and guidelines for the millennial generation when they participate in and participate in the democratic process of the people. The explanation in the book is written in detail in an easy-to-understand language without any connotations. The text content on each page is also neatly filled and very easy to read per important section. This book is also guided by the Law, Perbawaslu, and PKPU to minimize any double views on explanations related to election supervision.

However, on the other hand, this book has weaknesses, namely the lack of illustrations and the majority of which contain statutes. Regarding the explanation, many use paragraphs from articles written purely in the Law without any additional detailed information or explanatory descriptions of the points that exist. It causes the reader also to have to find out for themselves the meaning of each given article. This book is presented as an exciting solution to answering political challenges and some people's ignorance about elections. With a small size and easy to carry everywhere, this pilkada guide can undoubtedly be the answer. Because the continuity of elections will impact the running of the government for the next four years, it is necessary to have proper supervision and applicable guidelines.

Suci Madalena \& Moses Glorino Rumambo Pandin Universitas Airlangga

\section{REFERENCE}

Nafisah Khudrotun (2020), Buku Saku Millenial Mengawasi Pilkada 2020. Jombang: Tebuireng Institute

\section{AUTHOR SHORT-BIODATA}

Khudrotun Nafisah, S.Sos., M.Si. : Khudrotun Nafisah was born in Tuban on November 3, 1984. His undergraduate education with a major in Social Sciences was completed at the State University of Surabaya in 2008. Then he continued his S-2 education at the University of Muhammadiyah Malang with a Master of Science degree, which he completed in 2016. Currently, Khudrotun Nafisah has the status of a permanent lecturer and is still actively teaching at the University of Darul Ulum, Jombang, in the Department of Social Sciences. Apart from being a lecturer, he was also appointed as the Human Resources and Organizational Division Coordinator in the Jombang Bawaslu structure. Some of his experiences in the election are as a research team at the Under center for the 2017-2022 period and a member of the Bawaslu of Jombang Regency for the 2018-2023 period. Amid his busy life in education and politics, he also published another work, namely the Handbook for Handling Hate Speech in the 2019 Election Campaign. 